\title{
The calcareous mires in South-East Poland are home to two rare Anthracoidea species
}

\author{
MARCIN PIATEEK ${ }^{1}$ and WIESŁAW MUŁENKO ${ }^{2}$
}

\begin{abstract}
${ }^{1}$ Department of Mycology, W. Szafer Institute of Botany, Polish Academy of Sciences Lubicz 46, PL-31-512 Kraków, m.piatek@botany.pl (corresponding author) ${ }^{2}$ Department of Botany and Mycology, Maria Curie-Skłodowska University Akademicka 19, PL-20-033 Lublin, wieslaw.mulenko@poczta.umcs.lublin.pl
\end{abstract}

Piątek M., Mułenko W.: The calcareous mires in South-East Poland are home to two rare Anthracoidea species. Acta Mycol. 45 (2): 175-184, 2010.

The new collections of Anthracoidea buxbaumii Kukkonen on Carex buxbaumii Wahlenb. and Anthracoidea hostianae B.Lindeb. ex Nannf. on Carex lepidocarpa Tausch recorded in the calcareous mires in South-East Poland are described, illustrated and discussed. The holotype of the latter smut is also re-examined, described and illustrated in detail. Anthracoidea buxbaumii is reported for the second time from Poland on a new host plant. Anthracoidea hostianae is new to Poland. The variability of spore sizes of both species is discussed. The conspecificity of Anthracoidea buxbaumii and $A$. hostianae suggested in the literature is analyzed.

Key words: Ustilaginales, smut fungi, Carex, Europe

\section{INTRODUCTION}

The genus Anthracoidea Bref. (Ustilaginomycetes, Basidiomycota) includes about 80 described species distributed mostly, though not exclusively, in the arctic, boreal and temperate regions of the Holarctic Kingdom. The members of the genus are wellstudied in Europe, where 45 species are currently known (Vánky 1994). Twenty two species have been reported from Poland so far (Kochman, Majewski 1973; Piątek 2005; Piątek et al. 2005; Majewski et al. 2008). Like elsewhere in Central Europe, the greatest number of Anthracoidea species occurs in Poland in the mountains and uplands while fewer species are observed in huge lowland areas.

Large calcareous fens in the vicinity of Chełm, South-East Poland, are rich in rare and endangered vascular plants (Buczek, Buczek 1993; Mirek et al. 2005), including several remarkable species of Carex L. Two Anthracoidea species were recently collected on two different sedges growing in the Bagno Serebryskie Reserve and the 
Torfowisko Sobowice Reserve, respectively. The specimen from the Bagno Serebryskie Reserve recorded in the ovaries of Carex buxbaumii Wahlenb. is identified as Anthracoidea buxbaumii Kukkonen, a species previously known in Poland only from one station in the Polesie National Park on Carex hartmanii Cajander (Piątek et al. 2005). The collection from the Torfowisko Sobowice Reserve destroying ovaries of Carex lepidocarpa Tausch was similar to Anthracoidea hostianae B.Lindeb. ex Nannf., unknown from Poland until now, although it did not fully match the description of this species given by Nannfeldt (1979) in the protologue. Thus, we examined the holotype of Anthracoidea hostianae and compared it with the specimen collected in Poland, confirming their conspecifity.

Here we provide a full characterization of the newly recorded collections of $A n$ thracoidea buxbaumii and Anthracoidea hostianae, and discuss their morphological characters, including the variability of spore sizes, hosts and global distributions. Additionally, we discuss the conspecificity of Anthracoidea buxbaumii and A. hostianae suggested by Hendrichs et al. (2005).

\section{MATERIALS AND METHODS}

Sori and spore characteristics were studied using dried herbarium material. The herbarium specimens are deposited in KRAM, LBL, UPS and HeMP. The latter abbreviation refers to the personal, working collection of Marcin Piatek. The specimens were examined by light microscopy (LM) and scanning electron microscopy (SEM).

For light microscopy (LM), small pieces of sori were mounted in lactic acid, heated to the boiling point and cooled, and then examined under a Nikon Eclipse 80i light microscope. LM micrographs were taken with a Nikon DS-Fi1 camera. At least 50 spores were measured from each collection, using NIS-Elements BR 3.0 imaging software, and the variation is presented as a range, with extreme values (normally 1-3 spores per slide) given in parentheses. Mean and standard deviation calculated from $n$ spores is given in square brackets. Spore size values are also presented on the scatter diagrams to show the distribution of all the values.

Spore size ranges were categorized into three groups according to Savile (1952): (1) small-sized spores - 13-21(-23) $\times$ 9-17(-20) $\mu \mathrm{m}$; (2) medium-sized spores - 15$25(-27) \times 10-21 \mu \mathrm{m}$; (3) large-sized spores $-18-33 \times 13-28 \mu \mathrm{m}$. The spores of $\mathrm{An}$ thracoidea are usually more or less flattened and it is sometimes difficult to decide the position of the spore when measuring in LM - whether it is in plane view, side view or intermediately between these two positions (Nannfeldt, Lindeberg 1957; Kukkonen 1963). Thus, we measured the spores without distinguishing between plane view and side view. In such situations spore length is of greater taxonomical value than spore width as the full length is always visible in spores measured regardless of whether they are laid in plane view or side view (Nannfeldt, Lindeberg 1957; Kukkonen 1963).

For scanning electron microscopy (SEM), spores were dusted onto carbon tabs and fixed to an aluminum stub with double-sided transparent tape. The stubs were 


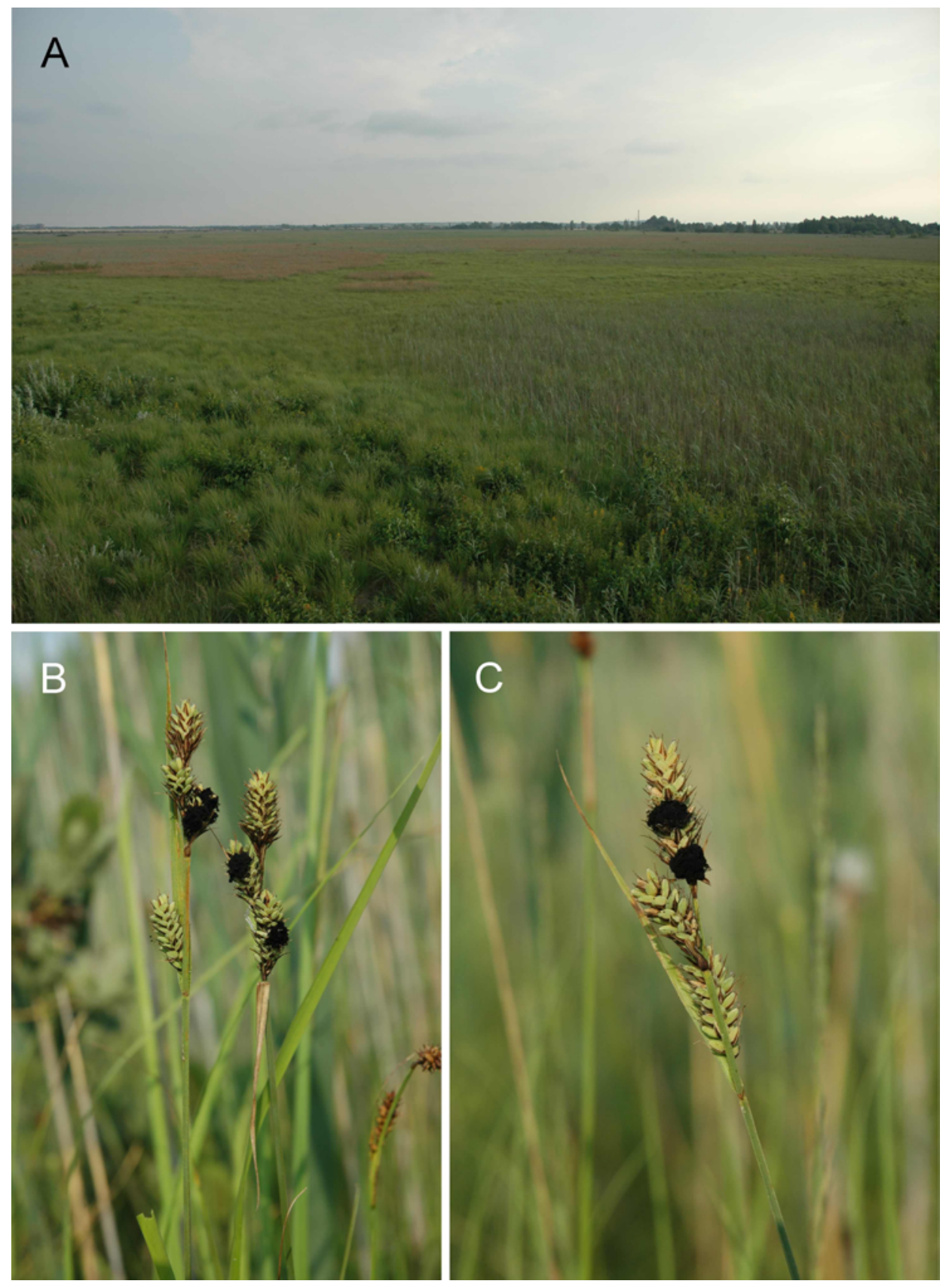

Fig. 1. A - Calcareous mire in the Bagno Serebryskie Reserve, a habitat for Anthracoidea buxbaumii; B, C - Sori of Anthracoidea buxbaumii in the ovaries of Carex buxbaumii. 

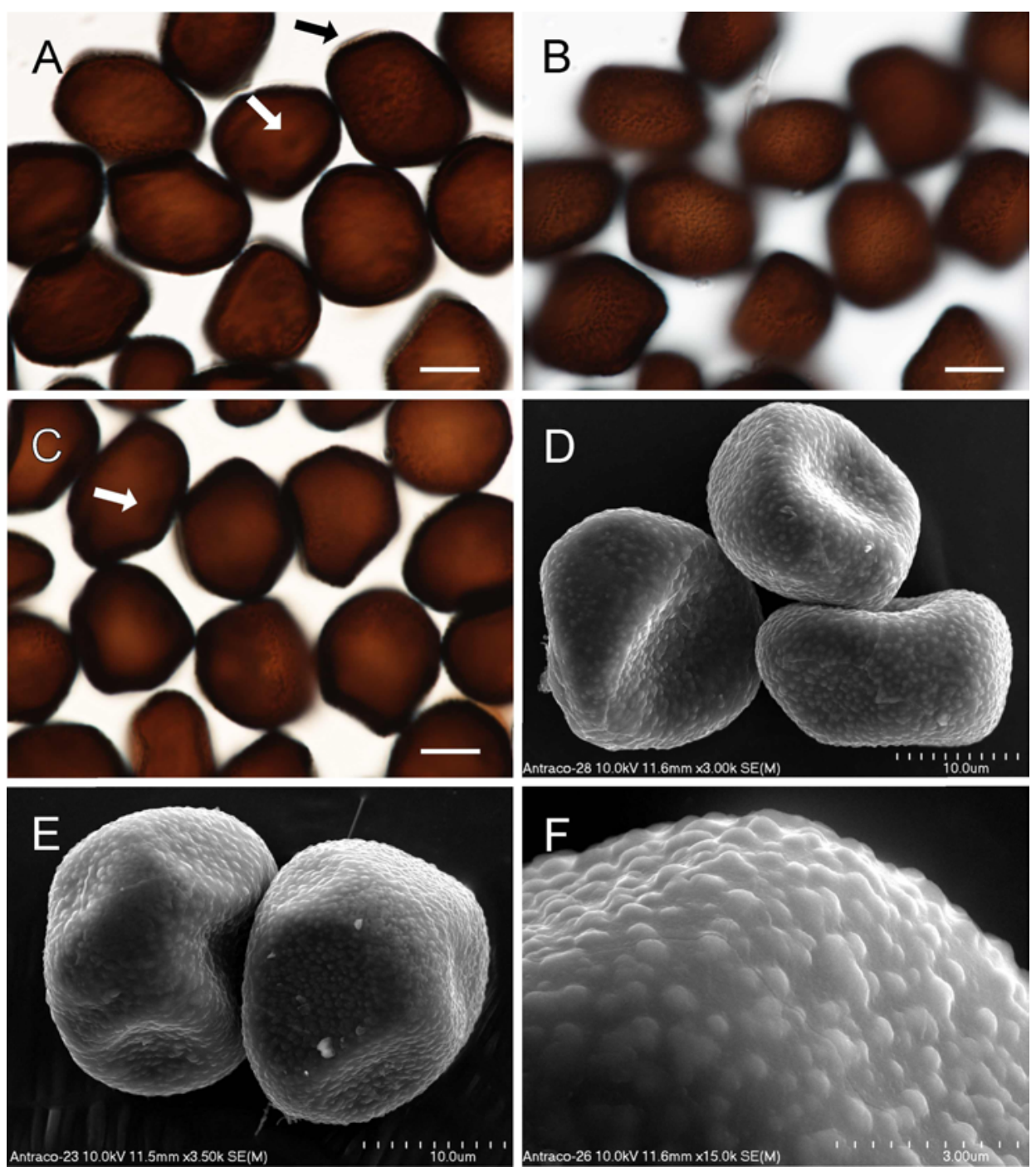

Fig. 2. Anthracoidea buxbaumii on Carex buxbaumii (KRAM F-48512): A-C - spores seen by LM, median (A \& C) and superficial (B) views. Note hyaline mucilaginous sheath indicated by black arrow, and internal swellings indicated by white arrows; D-E - spores seen by SEM; $\mathrm{F}-$ spore wall seen by SEM. Scale bars: A-E $=10 \mu \mathrm{m}, \mathrm{F}=3 \mu \mathrm{m}$. 
sputter-coated with carbon using a Cressington sputter-coater and viewed under a Hitachi S-4700 scanning electron microscope, with a working distance of ca 12-13 $\mathrm{mm}$. SEM micrographs were taken in the Laboratory of Field Emission Scanning Electron Microscopy and Microanalysis at the Institute of Geological Sciences of Jagiellonian University, Kraków (Poland).

\section{RESULTS AND DISCUSSION}

Anthracoidea buxbaumii Kukkonen

Figs $1-2$ and $3 \mathrm{~A}$

Ann. Bot. Soc. Zool.-Bot. Fenn. "Vanamo" 34(3): 88 (1963).

Sori in scattered ovaries of the inflorescences, 1-10 (usually several) sori per inflorescence, forming black, globose bodies around the nuts, about $1.5-3 \mathrm{~mm}$ in diameter, when young enclosed by a thin, silvery membrane, and covered by a perigynium, which later rupture revealing agglutinated spores, powdery on the surface, the sori and perigynia partly hidden by the scales, at maturity the sori disintegrate completely. Spores large-sized, moderately flattened, reddish-brown to dark reddishbrown, rounded, ellipsoidal, polyhedral, sometimes elongated and somewhat irregular, 19-28.7(-30.6) × (11.9-)14.1-22.8(-25.2) $\mu \mathrm{m}$ [av. \pm SD, 24.1 $\pm 3.1 \times 18.6 \pm 2.9 \mu \mathrm{m}$ $(n=70)$ ]; wall usually even, but sometimes uneven, 1-3 $\mu$ m thick, without protuberances and light-refractive spots, but with 1-3 indistinct internal swellings (difficult to see because of dark color of spores), sometimes enclosed by a very thin, hyaline, mucilaginous sheath; surface verruculose in LM, spore profile nearly smooth, finely wavy or finely serrulate, surface verruculose in SEM, warts rounded, up to $0.5 \mu \mathrm{m}$ high (measured from SEM micrographs).

Specimen examined. On Carex buxbaumii Wahlenb.: Poland, Polesie Wołyńskie, Obniżenie Dubieńskie: Bagno Serebryskie Reserve, ca $6 \mathrm{~km}$ NE of Chełm, calcareous mire (at the edge of and within communities with Phragmites australis (Cav.) Trin. ex Steud.), 14 July 2006, leg. J. Piątek \& M. Piątek (HeMP-120 = KRAM F-48512).

Location, HABITAT AND POPUlATION SIZE. The Bagno Serebryskie Reserve (376.62 ha) belongs to the Natura 2000 "Torfowiska Chełmskie" site. It is an extensive mire covered in great part by the Cladietum marisci community, but also by Caricetum buxbaumii, Schoenetum ferruginei and other plant associations. Anthracoidea buxbaumii was collected on plants growing at the edge of and within communities with Phragmites australis. We observed numerous infected plants in the northern part of the mire, but did not specifically search in other parts of the reserve where the smut can also be present. Anthracoidea buxbaumii is probably abundant at this site.

Comments. The present collection matches the original description of Anthracoidea buxbaumii (Kukkonen 1963) very well. More or less similar descriptions are offered by Nannfeldt (1979) and by Vánky $(1985,1994)$. In the two works by Vánky, the spore dimensions are exactly the same as those given in the protologue and therefore they are probably not original counts of the author. On the other hand, Braun \& Hirsch (1978) reported smaller spore size values for Anthracoidea buxbaumii [(19.5-)21-24.5(-25.5) × 16-21.5 um on C. adelostoma, (19-)21.5-23.5(-31) × 

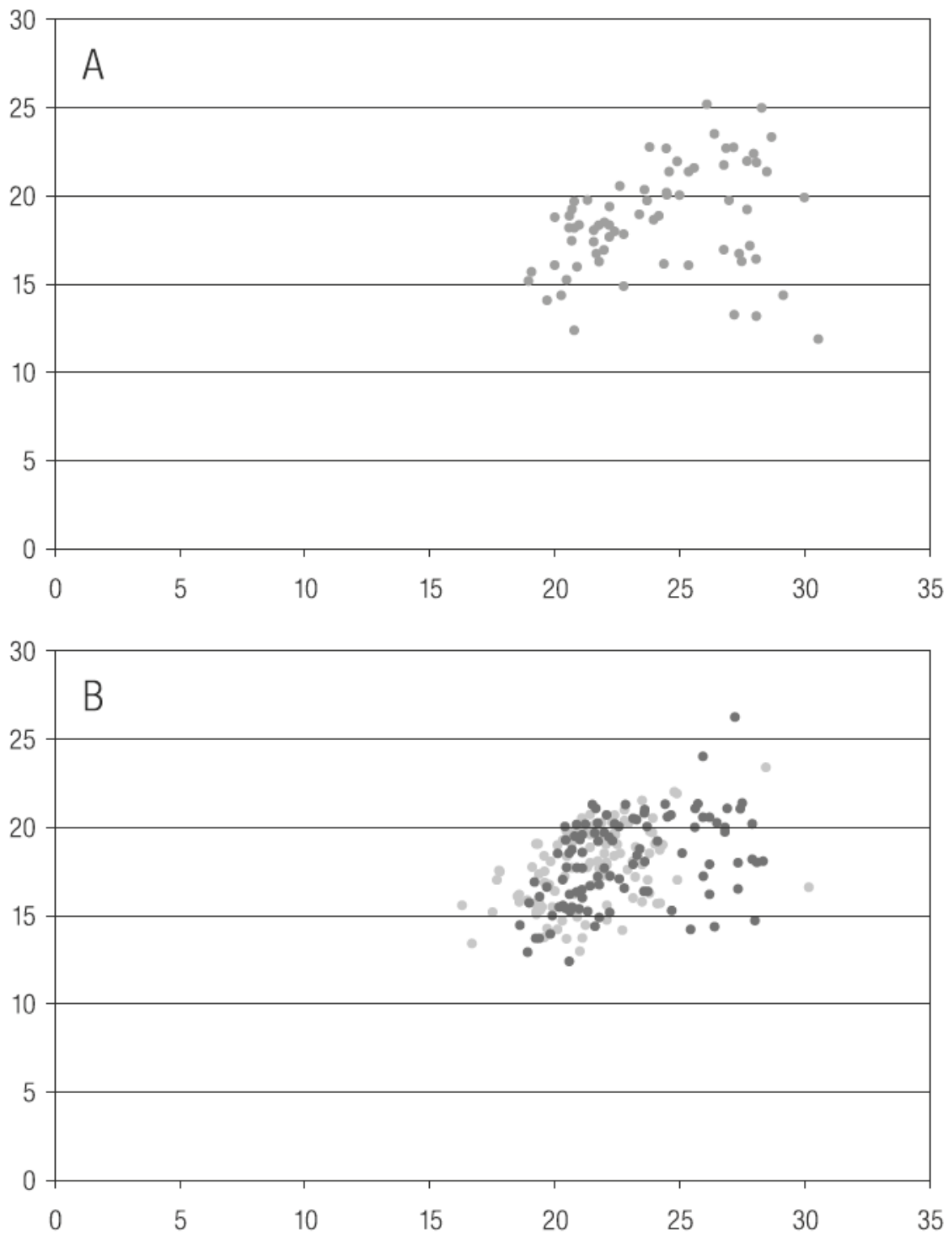

Fig. 3. Scatter diagrams of spore dimensions: A - Anthracoidea buxbaumii on Carex buxbaumii (KRAM F-48512) and B - Anthracoidea hostianae on Carex hostiana (holotype - UPS, grey circles) and Carex lepidocarpa (KRAM F-48513, light grey circles).

15-22 $\mu \mathrm{m}$ on $C$. hartmanii], which suggests variability of this character within various populations of the species. It is known that the spore size in different collections of the same species of Anthracoidea may be quite variable (Denchev 1991).

In Poland, Anthracoidea buxbaumii was previously known from only one locality on Carex hartmanii in the Bagno Bubnów within the Poleski National Park (Piątek et al. 2005). The present station is about $25 \mathrm{~km}$ south-east of this locality, on a new 
host plant. Both stations are situated in south-east Poland, and it is therefore likely that the species can be found in other calcareous mires in this part of the country. Nevertheless, the scrutiny of appropriate host plants in two phanerogamic herbaria (KRAM and LBL) did not reveal any additional specimen of the smut.

Through its geographical range, Anthracoidea buxbaumii is quite a rare species, perhaps more common only in Fennoscandia, known from Europe, North America and East Asia. The hosts are members of Carex section Racemosae (=Atratae). In Europe, the host plants are: Carex adelostoma V.I.Krecz. in Finland, Norway and Sweden (Kukkonen 1963), Carex buxbaumii in Finland, Norway, Poland (present record), Sweden and the European part of Russia (Kukkonen 1963; Nannfeldt 1979; Karatygin \& Azbukina 1989; Scholler et al. 2003), and Carex hartmanii in Hungary, Poland, Romania, Sweden, and Slovakia (Nannfeldt 1979; Vánky 1985; Paulech 1998; Piątek et al. 2005). In North America, Anthracoidea buxbaumii parasitizes C. adelostoma and C. buxbaumii in Canada and the U.S.A. (Alaska) (Kukkonen 1963). In East Asia it is known on Carex buxbaumii in Japan (Kakishima 1982) and on Carex gmelinii Hook. \& Arn. in Russian Far East (Sakhalin) (Karatygin \& Azbukina 1989). Generally, C. adelostoma and C. buxbaumii are two principal hosts of Anthracoidea buxbaumii, while Carex gmelinii and Carex hartmanii are tentatively treated as accessory hosts of the smut.

Anthracoidea hostianae B.Lindeb. ex Nannf.,

Figs 3B and 4-6 in Nannfeldt, Symb. Bot. Upsal. 22(3): 21 (1979).

The holotype on Carex hostiana - Sori in single ovaries of the inflorescences, usually 1 sorus per inflorescence, occasionally 3 sori in the inflorescence, forming black, globose or ovoid bodies, $2.5-3 \mathrm{~mm}$ in diameter, at first covered by a perigynium that

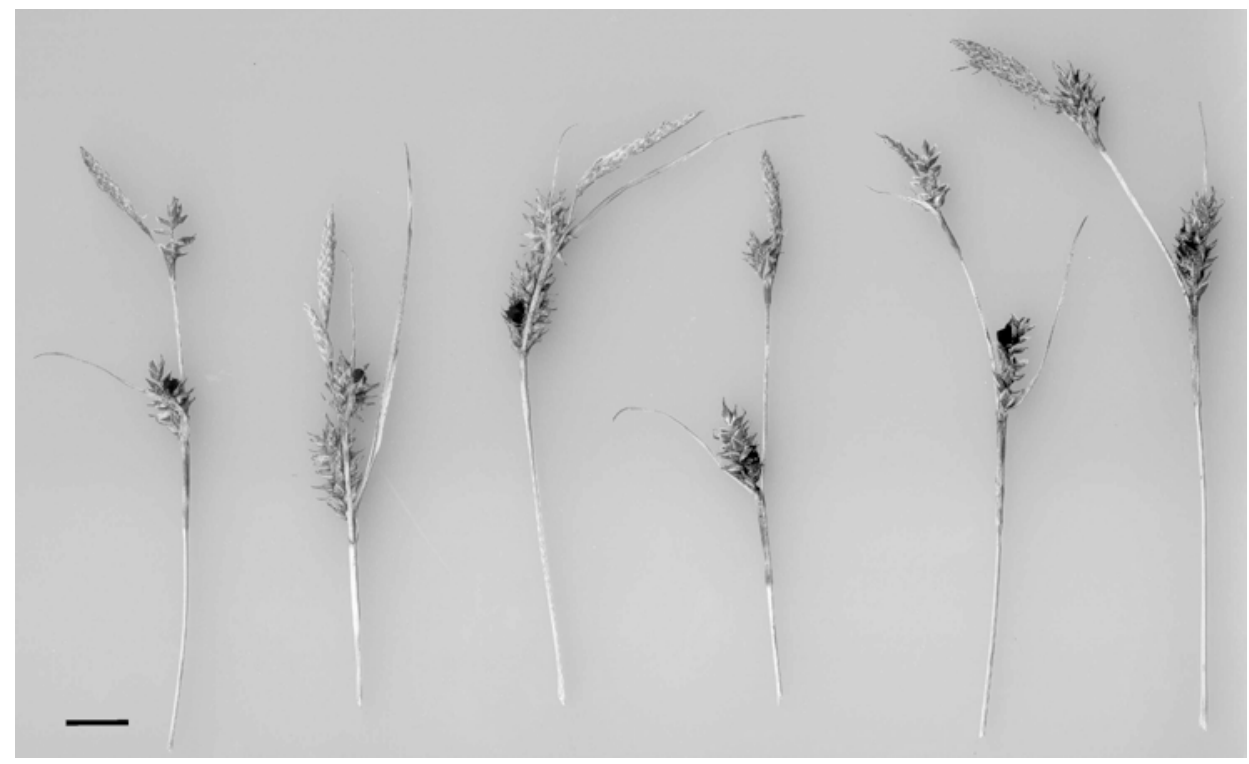

Fig. 4. Sori of Anthracoidea hostianae in the ovaries of Carex hostiana (holotype - UPS). Scale bar $=1 \mathrm{~cm}$. 
later ruptures, partly hidden by the scales; sori composed of agglutinated spores that become powdery on the surface with age and finally disintegrate completely. Spores large-sized, flattened, yellowish-brown to reddish-brown, globose, subglobose, ellipsoidal or somewhat irregular, (18.5-)19.1-27.9(-28.2) × (12.4-)14.0-21.4(-26.2) $\mu \mathrm{m}[\mathrm{av}$. $\pm \mathrm{SD}, 22.6 \pm 2.5 \times 18.1 \pm 2.5 \mu \mathrm{m}(n=120)]$; wall usually even, rarely uneven, $0.8-2.5$ $\mu \mathrm{m}$, without protuberances, but sometimes with light refractive spots and 1-2 indistinct internal swellings, rarely enclosed by thin hyaline, mucilaginous sheath; surface finely verruculose in LM, spore profile smooth or very finely wavy, surface verruculose in SEM, warts rounded, up to $0.5 \mu \mathrm{m}$ high (measured from SEM micrographs).

Specimen exAmined. "Flora Suecica. 16195. Cintractia Hostianae B. Lindeb. Matr.: Carex hostiana. Jämtland: Östersund, Odensala kalkkärr, 6.VIII.1959, leg. J. Ax. Nannfeldt“ (UPS - holotype).

Note. The holotype contains six plants of Carex hostiana DC. with smut sori five plants having one sorus in the inflorescence and one plant having three sori in the inflorescence, and several pieces of plant remains (mostly nuts) included in the foliar envelope. Additionally, the herbarium packet contains eight original LM micrographs probably made by John A. Nannfeldt and an annotation of María P. Martín (Madrid, Spain) that material was used for DNA studies, although to the best of our knowledge the sequence, if obtained, has not been published yet.

Polish collection on Carex lepidocarpa - Sori in single ovaries of the inflorescences, usually 1-3 sori per inflorescence, forming black, globose bodies, $1.5-2 \mathrm{~mm}$ in diameter, at first covered by a perigynium that later ruptures, partly hidden by the scales; sori composed of agglutinated spores that become powdery on the surface with age and finally disintegrate completely. Spores medium-sized, flattened, yellowish-brown to reddish-brown, globose, subglobose, ellipsoid, slightly angular, or very rarely somewhat elongated, (16.2-)19.0-24.8(-30.0) × 13.0-20.7(-23.4) $\mu \mathrm{m}$ [av. $\pm \mathrm{SD}$, $21.3 \pm 2.0 \times 17.7 \pm 2.1 \mu \mathrm{m}(\mathrm{n}=120)]$; wall quite even, $0.8-1.8 \mu \mathrm{m}$ thick (mostly 1.0-1.3 $\mu \mathrm{m}$ ), without protuberances, sometimes with light-refractive spots and 1-2 indistinct internal swellings, rarely enclosed by thin hyaline mucilaginous sheath; surface finely verruculose in LM, spore profile smooth or finely wavy, surface verruculose in SEM, warts rounded, up to $0.5 \mu \mathrm{m}$ high (measured from SEM micrographs).

Specimen examined: On Carex lepidocarpa Tausch: Poland, Polesie Wołyńskie, Pagóry Chełmskie: Torfowisko Sobowice Reserve, ca. $6 \mathrm{~km} \mathrm{SW}$ of Chełm, calcareous mire (in Molinietum caeruleae), 7 July 2005, leg. A. Buczek (HeMP-119 = KRAM F-48513 = LBL M 9048).

LOCATION, HABITAT AND POPULATION SIZE. The Torfowisko Sobowice Reserve (95.46 ha) protects a calcareous mire, including a unique cupola spring mire, and other natural communities with several unusual vascular plants. It entirely belongs to the Natura 2000 "Torfowisko Sobowice" site. Anthracoidea hostianae was collected on plants growing in the Molinietum caeruleae plant association. We have no direct information on the size of the population, but judging from the numerous specimens collected we assume that Anthracoidea hostianae is abundant at this locality.

Comments. Anthracoidea hostianae was first recognized, though never published, by Brita Lindeberg as Cintractia hostianae, and formally described by Nannfeldt (1979) in his revision of Nordic Anthracoidea species. According to the original description given in the protologue, the spores of $A$. hostianae are large, 18-29 $\times 15-25 \mu \mathrm{m}$, with mean length sizes, 20.5-21.5 $\mu \mathrm{m}$ (Nannfeldt 1979). The available descriptions 

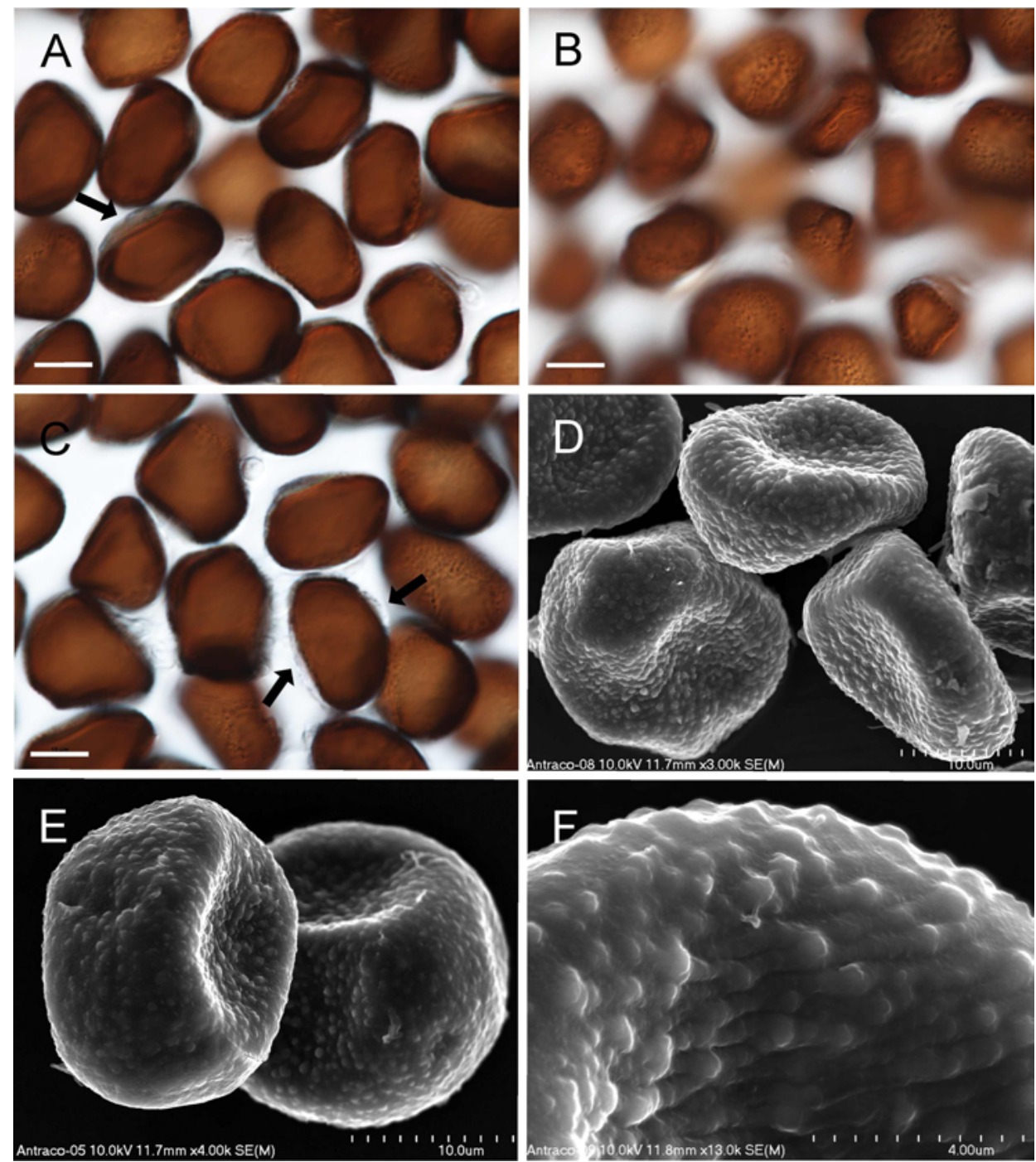

Fig. 5. Anthracoidea hostianae on Carex hostiana (holotype - UPS): A-C - spores seen by LM, median (A \& C) and superficial (B) views. Note hyaline mucilaginous sheath indicated by black arrows; D-E - spores seen by SEM; F - spore wall seen by SEM. Scale bars: A-E = 10 $\mu \mathrm{m}, \mathrm{F}=4 \mu \mathrm{m}$. 

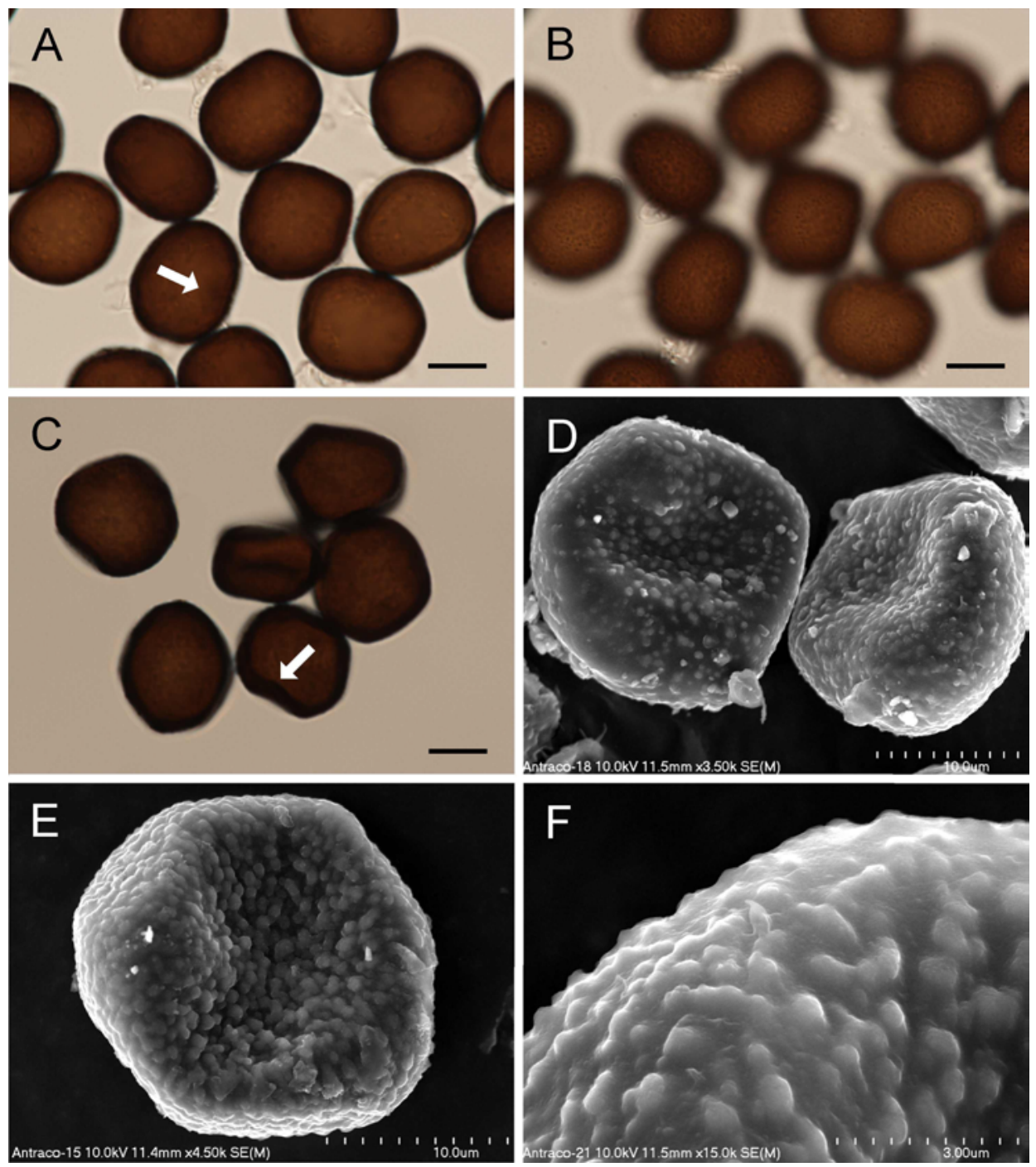

Fig. 6. Anthracoidea hostianae on Carex lepidocarpa (KRAM F-48513: A-C - spores seen by LM, median (A \& C) and superficial (B) views. Note internal swellings indicated by white arrows; D-E - spores seen by SEM; F - spore wall seen by SEM. Scale bars: A-E $=10 \mu \mathrm{m}$; $\mathrm{F}=3 \mu \mathrm{m}$. 
of $A$. hostianae, including spore sizes, offered by Vánky $(1985,1994)$ are actually almost exact copies (with slight modifications) of Nannfeldt's description. The spore size ranges obtained by Braun \& Hirsch (1978) and Pykälä et al. (1989) from nontype specimens are smaller, $(20-) 21-23(-24) \times 16.5-20.5 \mu \mathrm{m}$ and 19-25.5(-28) $\times(15-$ )16.5-21.5(-23) $\mu \mathrm{m}$, respectively.

The initial re-examination of the holotype of Anthracoidea hostianae revealed somewhat deviating characters from those described originally in the protologue. The spores were smaller according to our measurements, (18.9-)19.1-23.6(-27.2) $\times$ (12.4-)15.1-20.7(-21.3) um [av. $\pm \mathrm{SD}, 21.7 \pm 1.6 \times 18.3 \pm 2.1 \mu \mathrm{m}(n=60)]$, although the mean value of length was similar to mean values obtained by Nannfeldt (1979). We performed a second series of measurements from other sori from the holotype to verify the contradiction (difference). The values obtained in the second series, (18.5)19.3-27.9(-28.2) × (13.0-)14.0-21.4(-26.2) $\mu \mathrm{m}$ [av. \pm SD, 23.5 $\pm 2.9 \times 18.0 \pm 2.7 \mu \mathrm{m}$ $(n=60)$ ], were similar to those given in the protologue. Reasons for such measurement discrepancies are complex and depend on, for instance, the mounting medium, magnification, ocular type, maturity of sori, some environmental factors, etc. (Nannfeldt \& Lindeberg 1957; Kukkonen 1963). It is also worth noting that only extreme values are given by Nannfeldt (1979) and it is not clear how often spores with extreme values were observed in microscope slides.

The two series of measurements of Anthracoidea on C. lepidocarpa from Poland revealed almost identical values, (16.2-)19.2-23.8 × 13.0-20.7(-21.5) $\mu \mathrm{m}$ [av. $\pm \mathrm{SD}$, $20.9 \pm 1.6 \times 17.4 \pm 2.0 \mu \mathrm{m}(n=60)]$ and $(16.6-) 19.0-24.8(-30.0) \times(13.5-) 14.2-20.7(-$ 23.4) $\mu \mathrm{m}$ [av. $\pm \mathrm{SD}, 21.8 \pm 2.3 \times 18.0 \pm 2.3 \mu \mathrm{m}(n=60)]$, respectively. The values are

Table 1

Anthracoidea hostianae in the world, host plants and the most important sources of records

\begin{tabular}{|c|c|c|}
\hline Country & Host plants & References \\
\hline Austria & $\begin{array}{l}\text { C. flava, C. flava? } \times \text { C. hostiana, } \\
\text { C. hostiana, C. lepidocarpa }\end{array}$ & Pykälä et al. 1989, Zwetko 2003 \\
\hline Finland & $\begin{array}{l}\text { C. jemtlandica, C. flava } \times \text { C. jemtlandica, } \\
\text { C. flava }, \text { C. flava } \times \text { C. viridula, } \\
\text { C. hostiana (record unverifiable) }\end{array}$ & Nannfeldt 1979, Pykälä et al. 1989 \\
\hline Germany & C. hostiana, C. hostiana $\times$ C. lepidocarpa & Nannfeldt 1979, Scholz, Scholz 1988 \\
\hline Italy & C. hostiana & Nannfeldt 1979 \\
\hline Norway & C. hostiana & Nannfeldt 1979 \\
\hline Poland & C. lepidocarpa & this study \\
\hline Romania & $\begin{array}{l}\text { C. hostiana, C. hostiana } \times \text { C. lepidocarpa, } \\
\text { C. lepidocarpa }\end{array}$ & Nannfeldt 1979, Vánky 1985 \\
\hline $\begin{array}{l}\text { Russia } \\
\text { (Karelia) }\end{array}$ & C. jemtlandica, C. lepidocarpa & $\begin{array}{l}\text { Nannfeldt 1979, } \\
\text { Karatygin \& Azbukina } 1989\end{array}$ \\
\hline Slovenia & C. hostiana & Nannfeldt 1979, Lutz \& Vánky 2009 \\
\hline Spain & C. lepidocarpa & Almaraz \& Durrieu 1997 \\
\hline Sweden & $\begin{array}{l}\text { C. hostiana, C. hostiana } \times \text { C. jemtlandica, } \\
\text { C. hostiana } \times \text { C. lepidocarpa, C. hostiana } \\
\times \text { "C. oederi"** C. hostiana } \times \text { C. viridula, } \\
\text { C. flava } \times \text { C. hostiana }\end{array}$ & Nannfeldt 1979, Pykälä et al. 1989 \\
\hline Switzerland & C. hostiana & Nannfeldt 1979 \\
\hline Canada & C. flava $\times$ C. lepidocarpa & Pykälä et al. 1989 \\
\hline
\end{tabular}

* Nannfeldt (1979) reported the species on hybrid $C$. hostiana $\times C$. oederi without giving authorities of plant names. Carex oederi Retz. is a synonym of Carex pilulifera L. (Egorova 1999) and Carex oederi Ehrh. is a synonym of Carex viridula (Crins 2002). Nannfeldt's record probably refers to the latter species. 
smaller than those measured from the holotype of Anthracoidea hostianae, but, as stated above, the spore size in different collections of the same species of Anthracoidea may be quite variable (see Denchev 1991). Since other spore characters match the type of $A$. hostianae well and given spore variation, we treat the Polish collection as belonging to the species. This is the first record of the species in Poland. A special search in two phanerogamic herbaria (KRAM and LBL) did not yield any further specimen of the smut.

Anthracoidea hostianae is an almost exclusively European species, with one extralimital record from North America. It parasitizes diverse species of Carex belonging to the section Ceratocystis, and occurs on hybrids especially often (for a discussion of this phenomenon see Pykälä et al. 1989). In Europe, Anthracoidea hostianae is known on $C$. flava L., C. flava $\times$ C. hostiana, C. flava $\times$ C. jemtlandica (Palmgr.) Palmgr., $C$. flava $\times C$. viridula Michx., $C$. hostiana, C. hostiana $\times C$. jemtlandica, C. hostiana $\times$ C. lepidocarpa, C. hostiana $\times$ "C. oederi", C. hostiana $\times C$. viridula, $C$. jemtlandica and C. lepidocarpa from Austria, Finland, Germany, Italy, Norway, Poland, Romania, Russia (Karelia), Slovenia, Spain, Sweden, Switzerland. Detailed data on the host plants found infected in individual countries, together with the most important sources of records, are provided in Table 1 . The only North American collection is from Canada on C. flava $\times$ C. lepidocarpa, included in A. hostianae with some hesitation because the spores were smaller [15-21.5(-24) $\times(13-) 13.5-19(-19.5)$ $\mu \mathrm{m}]$ and the wall was thinner $(0.5-1.5 \mu \mathrm{m})$ than in European specimens (Pykälä et al. 1989).

\section{ANTHRACOIDEA BUXBAUMII and ANTHRACOIDEA HOSTIANAE: ONE OR TWO SPECIES?}

Molecular phylogenetic analyses of a selected number of Anthracoidea species (Hendrichs et al. 2005) revealed nearly identical LSU sequences of $A$. buxbaumii, $A$. hostianae (and A. lasiocarpae B.Lindeb., not studied here). Hendrichs et al. (2005) argued that these species are identical morphologically, have a similar germination type, their hosts occur sympatrically in the same locations, and thus their separateness may be questionable. Our data indeed show that Anthracoidea buxbaumii and $A$. hostianae are morphologically very similar. Additionally, both smuts were recorded in Poland in the same region, although not exactly at the same sites. On the other hand, the geographical distribution of these smuts in Europe is somewhat different. Anthracoidea buxbaumii is commonly found in Fennoscandia and only rarely penetrates central Europe. Anthracoidea hostianae is known in, though scattered, entire Europe. Anthracoidea lasiocarpae has been reported exclusively from Fennoscandia. It seems that it is only Fennoscandia where the three species meet together. If the three smuts do represent one species, then this raises the question: which factor affects such geographical variation in host susceptibility, especially that respective host plants are also present in western and central Europe. It is possible, however, that these are three separate although closely related species. It should be noted that LSU sometimes does not differentiate closely related species, and thus 
the analysis of DNA sequences from other regions is necessary to confirm or reject the conclusion reached by Hendrichs et al. (2005). We treat them as separate species until such studies have been conducted.

Acknowledgements. We thank Wojciech Paul (Kraków) for identifying Carex buxbaumii and Carex lepidocarpa, Jolanta Piątek (Kraków) for her help in field studies, Anna Łatkiewicz (Kraków) for her help with SEM pictures, and the Curator of UPS for the loan of specimen. The study was supported by the Polish Ministry of Science and Higher Education (grant no. 2 P04G 01928 for the years 2005-2008).

\section{REFERENCES}

Almaraz T., Durrieu G. 1997. Ustilaginales from the Spanish Pyrenees and Andorra. Mycotaxon 65: 223-236.

Braun U., Hirsch G. 1978. Übersicht über die europäischen Arten der Gattung Anthracoidea Bref. (Ustilaginales). Feddes Repert. 89: 43-60.

Buczek T., Buczek A. 1993. Carbonate marshes near Chełm - natural values, threats and protection. Chrońmy Przyr. Ojczystą 49 (3): 76-89.

Crins W. J. 2002. Carex Linnaeus sect. Ceratocystis Dumortier. (In:) Flora of North America North of Mexico, 23: 523-527. Oxford University Press, New York-Oxford.

Denchev C. M. 1991. Genus Anthracoidea Bref. (Ustilaginales) in Bulgaria - species and morphometric variability of the teliospores. Fitologija 41: 51-60.

Egorova T. V. 1999. The sedges (Carex L.) of Russia and adjacent states (within the limits of the former USSR). St.-Petersburg State Chemical-Pharmaceutical Academy, St.- Petersburg \& Missouri Botanical Garden Press, St. Louis.

Hendrichs M., Begerow D., Bauer R., Oberwinkler F. 2005. The genus Anthracoidea (Basidiomycota, Ustilaginales): a molecular phylogenetic approach using LSU rDNA sequences. Mycol. Res. 109: $31-40$

Kakishima M. 1982. A taxonomic study on the Ustilaginales in Japan. Mem. Inst. Agr. For. Univ. Tsukuba (Agr. For. Sci.) 1: 1-124.

Karatygin I. V., Azbukina Z. M. 1989. Opredelitel' gribov SSSR. Porjadok Golovnevye. Vyp. 1. Semejstvo Ustilagovye. Nauka, Leningrad.

Kochman J., Majewski T. 1973. Flora Polska. Grzyby. (Fungi). 5: Podstawczaki (Basidiomycetes), Głowniowe (Ustilaginales). PWN, Warszawa-Kraków.

Kukkonen I. 1963. Taxonomic studies on the genus Anthracoidea (Ustilaginales). Ann. Bot. Soc. Zool.Bot. Fenn. "Vanamo" 34 (3): 1-122.

Lutz M., Vánky K. 2009. An annotated checklist of smut fungi (Basidiomycota: Ustilaginomycotina and Microbotryales) in Slovenia. Lidia 7: 33-72.

Majewski T., Piątek M., Ruszkiewicz-Michalska M. 2008. Ustilaginales. (In:) W. Mułenko, T. Majewski, M. Ruszkiewicz-Michalska (eds). A preliminary checklist of micromycetes in Poland. (In:) Z. Mirek (ed.). Biodiversity of Poland 9: 297-318. W. Szafer Institute of Botany, Polish Academy of Sciences, Kraków.

Mirek Z., Nikel A., Paul W., Wilk Ł. (eds). 2005. Ostoje roślinne w Polsce. Instytut Botaniki im. W. Szafera, Polska Akademia Nauk, Kraków.

Nannfeldt J. A. 1979. Anthracoidea (Ustilaginales) on Nordic Cyperaceae-Caricoideae, a concluding synopsis. Symb. Bot. Upsal. 22 (3): 1-41.

Nannfeldt J. A., Lindeberg B. 1957. Taxonomic studies on the ovariicolous species of Cintractia on Swedish Caricoideae. Svensk Bot. Tidskr. 51: 493-520.

Paulech P. 1998. The genus Anthracoidea (Ustilaginales) in Slovakia. Bull. Slov. Bot. Spoločn., Bratislava 20: $20-26$.

Piątek M. 2005. Anthracoidea vankyi (Ustilaginomycetes) in Poland, with a review of its host spectrum and world distribution. Acta Mycol. 40: 95-101.

Piątek M., Ruszkiewicz-Michalska M., Mułenko W. 2005. Catalogue of Polish smut fungi, with notes on four species of Anthracoidea. Polish Bot. J. 50: 19-37.

Pykälä J., Salo V., Toivonen H. 1989. On the ecology and distribution of Anthracoidea hostianae (Ustilaginales). Ann. Bot. Fenn. 26: 149-155. 
Savile D. B. O. 1952. A study of the species of Cintractia on Carex, Kobresia, and Scirpus in North America. Canad. J. Bot. 30: 410-435.

Scholler M., Schnittler M., Piepenbring M. 2003. Species of Anthracoidea (Ustilaginales, Basidiomycota) on Cyperaceae in Arctic Europe. Nova Hedwigia 76: 415-428.

Scholz H., Scholz I. 1988. Die Brandpilze Deutschlands (Ustilaginales). Englera 8: 1-691.

Vánky K. 1985. Carpathian Ustilaginales. Symb. Bot. Upsal. 24 (2): 1-309.

Vánky K. 1994. European smut fungi. G. Fischer Verlag, Stuttgart-Jena-New York.

Zwetko P. 2003. Zur Kenntnis der Rost- und Brandpilze Österreichs. Fritschiana 42: 77-82.

Torfowiska węglanowe w południowo-wschodniej Polsce stanowią siedlisko dla dwóch rzadkich gatunków Anthracoidea

\section{Streszczenie}

W pracy opisano, zilustrowano i przedyskutowano nowe kolekcje Anthracoidea buxbaumii Kukkonen na Carex buxbaumii Wahlenb. oraz Anthracoidea hostianae B.Lindeb. ex Nannf. na Carex lepidocarpa Tausch znalezione na torfowiskach węglanowych w południowo-wschodniej Polsce. Dodatkowo szczegółowo opisano i zilustrowano holotyp tego ostatniego gatunku głowni. Anthracoidea buxbaumii została stwierdzona po raz drugi w Polsce na nowej roślinie żywicielskiej. Anthracoidea hostianae jest nowym dla Polski gatunkiem głowni. Przedyskutowano problem zmienności wielkości zarodników obydwu gatunków oraz przeanalizowano sugerowaną w literaturze koncepcję tożsamości gatunkowej Anthracoidea buxbaumii oraz A. hostianae. 